\title{
The effect of aerosol treatment with calcium- based preparation on quality of table grape cultivar during storage
}

\author{
Sofia Cherviak ${ }^{1, *}$, Svetlana Levchenko ${ }^{1}$, Vladimir Boyko ${ }^{1}$, and Dmitriy Belash ${ }^{1}$ \\ ${ }^{1}$ All-Russian National Research Institute of Viniculture and Winemaking "Magarach" of RAS, \\ Kirova Str, 31, Yalta, 298600, Republic of Crimea, Russian Federation
}

\begin{abstract}
The main problems of grape storage are berry dehydration and rot. One of the solutions to reduce rot and preserve the quality of grapes during storage is the use of aerosol treatment with calcium content before storing. The aim of the study was to evaluate the effect of physiologically active substances based on calcium in various concentrations on the quality and organoleptic characteristics of table grape cvs. 'Italia' during long-term storage. The effectiveness of the studied systems of treatment was evaluated according to the content of sugars and titratable acids, the activity of the redox enzymes of polyphenol oxidase and peroxidase, weight loss of bunch and organoleptic properties. The greatest effectiveness established by using preparation of Master Green $\mathrm{Ca}$, Brentax $\mathrm{KCa}$, and Brentax $\mathrm{Ca}$ (in concentration $150 \mathrm{~g} / 201)$. Experimental treatments significantly decreased the weight loss of bunch (less than $4 \%$ ), and preserved organoleptic properties of berry at a high level (8.2-8.9 points). Decrease in the activity of oxidative enzymes had a positive effect on the quality of table grapes and contributed to its better preservation. The data obtained make it possible to rationalize the system of long-term storage of grapes by using of aerosol treatment with calcium-based preparation.
\end{abstract}

\section{Introduction}

The main problems of grape storage are berry dehydration and rot. These phenomena can be reduced by technological approaches that help to inhibit respiration processes, as a result of which metabolic activity decreases and the organoleptic properties of grapes are preserved. One of these technological approaches is the use of various growth regulators in aerosol treatment in the post-harvesting period $[1,2,3,4]$.

The main technologies for maintaining product quality during storage are aimed at inhibiting physiological processes, in particular, excessive accumulation of ethylene and its biological action $[5,6,7]$.

Another alternative is the use of nonorganic salts for plants, in particular with calcium content. The studies have shown that calcium plays an important role in the growth and development of fruits: it contributes to the optimal water balance between the pericarp and

\footnotetext{
* Corresponding author: Sofi4@list.ru
} 
the internal fruit tissues, supports the elasticity and resilience of the cell walls [8]. The mechanism of work of calcium is based on protecting the membrane structure, reducing the destructive effect on cell walls and stabilizing the membrane system [9, 10]. The use of physiologically active calcium-based substances reduces the risk of the pathogen entry into plant tissues, stimulates defense mechanisms $[11,12]$.

The important role of calcium is also determined in the grape storage. It is known that the more calcium is contained in a berry, the greater and longer its preservation period, due to the increased resistance of products to pathogens and the content of secondary metabolites phenolic substances, stilbenes in particular [13].

The aim of the study is to evaluate the effect of physiologically active substances based on calcium in various concentrations on the quality and organoleptic characteristics of table grapes during storage.

\section{Materials and methods}

\subsection{Parameters of harvesting and post-harvest processing of grapes}

A commercial vineyard of 'Italia' table grape was selected in the mountain-valley seaside region of Crimea in industrial-agrarian association "Massandra", (v. Morskoye). The studies were conducted in 2018.

The studied grapevine culture was uncovered. The planting scheme for table grapes was $3.0 \times 1.5 \mathrm{~m}$. The bush form was a three-branch fan-shaped vine. The training system was a vertical trellis.

The sample amount was 25 pieces in 3 replicates for each variant of the experiment. During the harvesting we calculated the number of bunches per bush, bunch weight and the yield. To study the chemical composition of grape berry were taken samples from five grape bunches of each scheme replication. To determine the natural loss of weight, batches by five boxes containing four bunches each, were formed and packed in a polymer grid with a mesh diameter of $0.5 \mathrm{~cm}$.

The experimental scheme of post-harvest processing of grapes before laying for longterm storage called for aerosol treatment [14]. Calcium preparations were used: Brentax Ca - a calcium-based bioactivator $(\mathrm{Ca})$, formulated by the ITM complex (Metabolic Translocation Inducer); Brentax $\mathrm{KCa}$ - a potassium $(\mathrm{K})$ and calcium $(\mathrm{Ca})$ based bioactivator formulated by the ITM complex; Master Green $\mathrm{Ca}$ - a preparation based on lignin and polycarboxylic acids. Processing was carried out in a special spraying chamber with a volume of 378 liters, where a box with grapes weighing 11-12 kg was placed. Concentrations of working solutions were: for Brentax $\mathrm{Ca}-50,75$ and $150 \mathrm{~g}$ per 201 of water, Brentax $\mathrm{KCa}$ $50 \mathrm{~g} / 201$, Master Green $\mathrm{Ca}-35 \mathrm{~g} / 201$. The solution was fed for $20 \mathrm{sec}$. through injectors at a pressure of 0.2 MPa. Storage of fresh grapes was provided at a temperature of $0-+2{ }^{\circ} \mathrm{C}$ and relative air humidity of $90-95 \%$ for 90 days. The control was the production technology of storage in an industrial refrigerator with regular treatment with sulfur dioxide. The studies were carried out in four replicates of every variant of the experiment.

The effectiveness of the studied systems of treatment was evaluated according to the following parameters: the content of sugars and titratable acids, the activity of the redox enzymes of monophenol monooxygenase (polyphenol oxidase, PPO) and peroxidase (POD), weight loss of bunch (WL), and tasting assessment (TA). 


\subsection{Sample preparation and chemical analysis of grapes}

For research, samples of grapes with a mass concentration of sugars 17.5-21.0 g/l and titratable acids 4.0-5.9 g/l were selected, according to the requirements of state industry standard "Fresh table grapes. Storage in controlled atmosphere refrigerating chambers". To determine the mass concentration of sugars we used aerometric method, to determine the titratable acids we used titrimetric method with recount for tartaric acid [15].

The value of weight loss of bunch was calculated as a ratio of a bunch weight after storage and before its laying, multiplied by $100 \%$.

Tasting assessment (TA) of grape samples was provided using 10-point scale including the following parameters: "appearance of bunch and berries", "flavor and aroma" and "texture of skin and pulp of berries."

The polyphenol oxidase and peroxidase activity were studied in freshly squeezed juice after whole berries were pressed. Polyphenol oxidase and peroxidase activities were evaluated by the rate of formation of a blue-violet color of oxidized diethyl paraphenylenediamine sulfate and benzidine respectively [14].

\subsection{Statistical analysis of the data}

All analytical studies were performed in triplicate. The arithmetic mean and standard deviation (SD) were determined by the statistical method (SPSS Statistics 17.0). Statistically significant differences between means were identified based on Fisher LSDtest at $\mathrm{P}<0.05$ level.

\section{Results and Discussion}

The analysis of the qualitative characteristics of grapes showed that after 30 days of storage, the mass concentration of sugars in all experimental grape samples was higher than the control value (Fig. 1). The variants of experiment using Brentax $\mathrm{KCa}$ and Master Green $\mathrm{Ca}$ preparations were characterized by the maximum content of the component. After 90 days of storage, behavior of sugars in berry was marked by a reverse direction - the content of the component was 1.0-2.1 g/l lower than the control in all variants of the experiment.

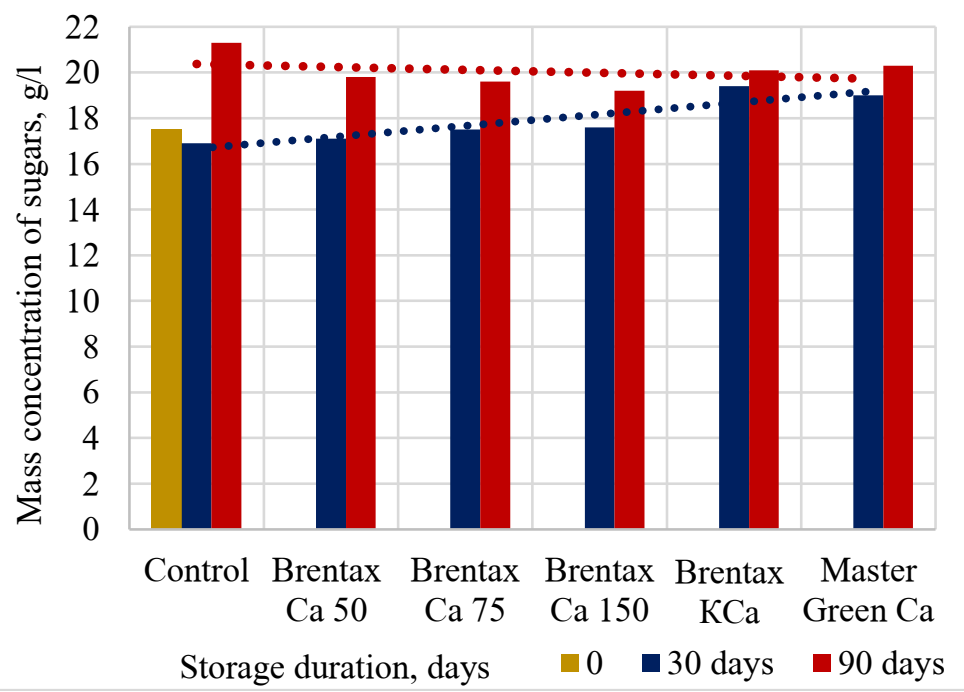

Fig. 1. The sugar content in grapes processed using the control and experimental variants 
The opposite dynamics was observed for mass concentration of titratable acids (Table 1), where the value by the end of storage exceeded the entries of the control variant by $0.5-1.2$ $\mathrm{g} / \mathrm{l}$.

This tendency of changes in the conditional parameters of grapes indicates that the studied method (aerosol treatment with calcium-based preparations) helps to reduce the intensity of water evaporation and redox processes, and organic acids as some of their substrates.

The main losses of table grapes when using the storage technology are due to the weight loss of bunch. The maximum weight loss due to natural loss in the control variants was observed during the first 30 days of storage and amounted to $2.3-3.2 \%$ of the initial value. In the next 60 days of storage, the losses decrease and vary in the range of $0.8-1.4 \%$. It is noted that the minimum values of the weight loss of bunch were observed for grape samples using experimental treatment schemes with preparations Master Green $\mathrm{Ca}$, Brentax $\mathrm{KCa}$, and Brentax Ca (at a concentration of $150 \mathrm{~g} / 201$ ).

When storing table grapes the activity of oxidative enzymes undergoes significant quantitative shift due to changes of environmental conditions, as well as metabolic processes going on in the berry. Analysis of the data showed that during storage the activity of polyphenol oxidase is characterized by nonlinear dynamics: by the end of 30 days of storage in the control sample, the activity of the enzyme was $38 \%$ higher than at the time of laying for storage, after which it decreased by $55 \%$. It should be noted that all studied treatment schemes provided a decrease in the activity of polyphenol oxidase, and in quantitative concept they were below the control. Variants of experiments using preparations Brentax $\mathrm{Ca}$ at the maximum dosage, Brentax $\mathrm{KCa}$ and Master Green $\mathrm{Ca}$ at 17.5, 15.6 and 19.7 c.u. respectively, were characterized by minimum values of the parameter by the end of storage.

Table 1. Changes in biochemical parameters of grapes during long-term storage

\begin{tabular}{|c|c|c|c|c|c|c|c|}
\hline \multirow[t]{2}{*}{$\begin{array}{l}\text { Time of } \\
\text { storage }\end{array}$} & \multirow[t]{2}{*}{$\begin{array}{l}\text { Experiment } \\
\text { option }\end{array}$} & \multirow[t]{2}{*}{$\begin{array}{c}\text { Mass } \\
\text { concentration } \\
\text { of titratable } \\
\text { acids, } \mathrm{g} / \mathbf{l}\end{array}$} & \multirow[t]{2}{*}{ pH } & \multicolumn{2}{|c|}{$\begin{array}{c}\text { Enzyme } \\
\text { activity, } \\
\text { c.u. } / \mathbf{c m}^{3}\left(\mathbf{x} 10^{2}\right) \\
\end{array}$} & \multirow[t]{2}{*}{ LW, \% } & \multirow[t]{2}{*}{ TA, points } \\
\hline & & & & PPO & POD & & \\
\hline Entry & Control & 4.9 & 3.2 & 34.1 & 0.79 & - & 9.0 \\
\hline \multirow{6}{*}{30 days } & Control & 5.5 & 3.2 & 46.9 & 6.82 & 2.7 & 7.8 \\
\hline & Brentax Ca 50 & 5.1 & 3.4 & 22.1 & 1.29 & 3.2 & 8.0 \\
\hline & Brentax Ca 75 & 5.5 & 3.3 & 31.3 & 1.56 & 2.8 & 8.0 \\
\hline & Brentax Ca 150 & 5.6 & 3.4 & 31.3 & 1.56 & 2.4 & 81 \\
\hline & Brentax KCa & 4.9 & 3.6 & 62.5 & 1.44 & 2.5 & 8.4 \\
\hline & Master Green $\mathrm{Ca}$ & 5.1 & 3.5 & 26.8 & 1.6 & 2.3 & 8.6 \\
\hline $\mathrm{LSD}_{05}$ & - & 0.34 & 0.31 & 0.32 & 0.03 & 0.27 & 0.32 \\
\hline \multirow{6}{*}{90 days } & Control & 3.9 & 3.5 & 20.8 & 0.8 & 4.1 & 7.1 \\
\hline & Brentax Ca 50 & 4.5 & 3.4 & 20.8 & 0.88 & 4.2 & 7.0 \\
\hline & Brentax Ca 75 & 4.9 & 3.4 & 25.0 & 0.99 & 4.0 & 8.2 \\
\hline & Brentax Ca150 & 5.1 & 3.3 & 37.5 & 1.19 & 3.5 & 8.2 \\
\hline & Brentax KCa & 44 & 3.3 & 15.6 & 0.83 & 3.6 & 8.3 \\
\hline & Master Green $\mathrm{Ca}$ & 4.5 & 3.4 & 19.7 & 0.89 & 3.1 & 8.5 \\
\hline $\operatorname{LSD}_{05}$ & - & 0.27 & 0.37 & 0.30 & 0.03 & 0.30 & 0.30 \\
\hline
\end{tabular}

Similar tendency in the dynamics of storage was noted for the activity of peroxidase. However, it should be mentioned that the value of the parameter in the control sample after 30 days of storage increased by 8.6 times, while in all experimental variants the increase was 1.6-2.0 times. By the end of storage, no significant effect of treatment on peroxidase activity was established.

Analysis of the tasting assessment of table grapes in the dynamics of post-harvest storage showed that the use of calcium-based preparations gives a positive effect on organoleptic 
indicators of the studied grape samples, as well as the establishment of this indicator in the dynamics of grapes storage. It was found that the experimental samples of grapes were characterized by higher values of the tasting assessment relative to the control during the entire period of storage. It was also noted that a decrease in the activity of oxidative enzymes had a positive effect on the quality of table grapes and contributed to a better preservation. Maximum values of the tasting assessment of grapes by the end of storage (90 days) were observed in the experimental variants with Master Green $\mathrm{Ca}-8.5$ points, Brentax $\mathrm{KCa}-8.3$ points, Brentax $\mathrm{Ca}$ (at a concentration of $150 \mathrm{~g} / 201$ ) -8.2 points.

\section{Conclusion}

Based on the results of the research, the following conclusions were obtained:

1. The highest efficiency of aerosol treatment before laying for storage was found when using calcium-based preparations Master Green $\mathrm{Ca}$, Brentax $\mathrm{KCa}$, as well as Brentax $\mathrm{Ca}$ (at a concentration of $150 \mathrm{~g} / 201)$.

2. The experimental variants were characterized by the minimum value of the weight loss of bunch (no more than $3 \%$ and $4 \%$ after 30 and 90 days of storage, respectively), as well as the preservation of high organoleptic properties of the berry (8.2-8.5 points).

3. It was noted that a decrease in the activity of the oxidative enzyme polyphenol oxidase had a beneficial effect on the quality of table grapes and contributed to a better preservation.

4. In variants of the experiment with a lower concentration of introduced preparations, a significant effect on biochemical parameters and indicators of commercial quality was not established.

5. The data obtained make it possible to rationalize the system of long-term storage of grapes owing to the use of aerosol treatment with the studied preparations.

\section{References}

1. F.C. de Almeida, J.F. Cham, B.L. Ham, et al., BIO Web of Conferences 3, 1 (2014)

2. I. Maya-Meraz, R. Pérez-Leal, J. Ornelas-Paz, J. Jacobo-Cuéllar, M. Rodríguez-Roque, R. Yanez-Munoz, A. Cabello-Pasini, SASEV. 41(1), 1-11 (2020)

3. M.W. Siddiqui, Preharvest Modulation of Postharvest Fruit and Vegetable Quality, 93120 (Academic Press ELSEVIER, 2018).

4. F.C. de Almeida, J.F.L. de C. Cham, B.L. Hamm, S.M. Ferreira, M. Gabbardo, J. Saavedra del Aguila, Bio Web of Conferences, 3, 01003 (2014)

5. J.M. Silveira, E.N. Fernandes, B.L. Hamm, et al., RS BIO Web of Conferences 7 (2016)

6. A. Gayed, S. Shaarawi, M. Elkhishen, N. Elsherbini, Ciência e Agrotecnologia 41(2), 220-231 (2017)

7. M. Serrano, P.J. Zapata, D. Martínez-Romero, H.M. Díaz-Mula, D. Valero, Eco-Friendly Technology for Postharvest Produce Quality (Academic Press, London, 2016)

8. T.M. Gomes, L.F. Mazon, C.P. Panceri, et al., Sci of Food and Agriculture 100(4), 1547 (2020)

9. L. Zhang, J. Wang, B. Zhou, G. Li, Y. Liu, X-L. Xia, Z. Xiao, L. Fei, S. Ji, Sci Hortic. 244, 15 (2019)

10. S. Davarpanah, A. Tehranifar, J. Abadía, J. Val, G. Davarynejad, M. Aran et al., Sci Hortic. 230, 86 (2018)

11. O. Yakhin, A. Lubyanov, I. Yakhin, P. Brown, Front. Plant Sci. 7, 2049 (2016) 
12. D. Maurer, O. Feygenberg, A. Tzoor, G. Atzmon, S. Glidai, D. Prusky, Horticulturae 5, 23 (2019)

13. A. Batukaev, S. Levchenko, E. Ostroukhova, V. Boiko, I. Peskova, P. Probeygolova, D. Belash, N. Lutkova, BIO Web of Conferences 15, 01012 (2019)

14. D. Belash, V. Boiko, Magarach. Viticulture and Winemaking 20, 9 (2018) (in Russian)

15. Compendium of international methods of wine and must analysis (International organization of vine and wine, Paris, 2017) 